\title{
Crude oil and refined products transportation from the Caspian region to the European Union
}

\author{
E. Akhmedov* \\ Strategic Consultants LLP \\ Kabanbay Batyr St. 71, 050010 Almaty, Kazakhstan \\ *e-mail: e_akhmedov@ hotmail.com
}

Submitted: 27/11/2020; Accepted: 02/02/2021; Published online: 09/02/2021

Abstract: This article provides in-depth description of the situation with crude oil and refined products transportation from the Caspian Region to the European Union. It describes demand and supply, main transportation routes and modes of transport. The article then addresses existing and potential issues and discusses the ways to resolve them. There are two knowledge gaps associated with the topic of this article: (i) transportation of crude oil and refined products from the Caspian region to the European Union receives limited attention of researchers, and (ii) the majority of related scientific publications consider mainly the aspects of geopolitics and the European energy security, but not the transportation itself. The author attempts to partially close these gaps.

Keywords: Caspian region; European Union; transportation; crude oil; refined products

\section{Introduction}

As rightly mentioned [1] „The economy of Europe depends on energy imports, while the economy of the Caspian region depends on energy exports." Though relatively close geographically, these two regions are still distant from each other. This determines the importance of transportation.

The Caspian region is represented by Azerbaijan, Iran, Kazakhstan, Russia and Turkmenistan. These countries have similar logistics performance indices (LPIs), significantly lower compared to the LPIs of more developed countries. Please see Table 1 below. 
Table 1. LPIs of the Caspian countries and selected sample countries [2]

\begin{tabular}{|c|c|c|c|c|c|c|c|c|c|}
\hline & \multicolumn{5}{|c|}{ Caspian countries } & \multicolumn{3}{c|}{ Sample countries } \\
\hline & AZ & GE & IR & KZ & RU & TM & CN & DE & HU \\
\hline 2007 & 2.29 & - & 2.51 & 2.12 & 2.37 & - & 3.32 & 4.1 & 3.15 \\
\hline 2010 & 2.64 & 2.61 & 2.57 & 2.83 & 2.61 & 2.49 & 3.49 & 4.11 & 2.99 \\
\hline 2012 & 2.48 & 2.77 & 2.49 & 2.69 & 2.58 & - & 3.52 & 4.03 & 3.17 \\
\hline 2014 & 2.45 & 2.51 & - & 2.7 & 2.69 & 2.3 & 3.53 & 4.12 & 3.46 \\
\hline 2016 & - & 2.35 & 2.6 & 2.75 & 2.57 & 2.21 & 3.66 & 4.23 & 3.43 \\
\hline 2018 & - & 2.44 & 2.85 & 2.81 & 2.76 & 2.41 & 3.61 & 4.2 & 3.42 \\
\hline
\end{tabular}

AZ - Azerbaijan, GE - Georgia, IR - Iran, KZ - Kazakhstan, RU - Russia, DE Germany, CN - China, HU - Hungary

Considering crude oil and refined products deliveries from this region to the European Union, we need to take into consideration the following:

- The Caspian region is one of the closest to Europe major producers of hydrocarbons;

- It has been and will be one of the main suppliers of hydrocarbons to the European market. Three out of five Caspian countries (Azerbaijan, Kazakhstan and Russia) are the largest suppliers of crude oil and refined products to the European Union. At the same time, most of the Russian crude oil production originated from the regions other than Caspian;

- The regional infrastructure for transportation of crude oil and refined products is well developed and is mainly aimed at supplies to Europe.

The points above define the crucial role of the transport corridors for supplying crude oil and refined products to Europe.

It is important to have a comprehensive picture of the situation. This is why the article looks at it from different angles considering demand, supply, transportation and different other factors.

\section{Literature review}

The topic of transportation of crude oil and refined products from the Caspian region to the European Union has received limited attention of researchers in comparison with deliveries from the Gulf area. Another circumstance, which 
complicates this research further, is that the majority of existing scientific publications, i.e. [3-5] and many others, consider mainly the aspects of geopolitics and the European energy security. These two circumstances constitute two major knowledge gaps and this article attempts to partially close them.

The number of scientific works addressing the transportation from the region is not substantial, but such works exist and are considered in this Literature review. For example, [6] discusses the EU's leading role in developing the Caspian - Black Sea - Europe energy bridge to „ensure that at the very least Eastern European states diversify their energy sources and develop transit infrastructure." In his view „Europe needs to employ generally pro-active policies toward the Black Sea/Caspian region, which should include: ... Promotion and political and financial support for Trans-Caspian and Trans-Black Sea energy infrastructure to ensure alternative energy supplies to Europe from the Caspian region". [7] warned back in 2010 that „While the recent launch of a long-awaited cross-border oil pipeline between Russia and China has received most of the publicity, it is a part of a much larger Russian initiative aimed at developing new oil export infrastructure in almost every possible direction: Asia, the Baltic Sea region, the Black Sea region, and the Arctic. This export strategy will have considerable policy and economic implications for Eastern and Central Europe..." [8] undertake „A close analysis of contemporary and historical extraction of Caspian oil and its transportation, via pipeline and tanker, to central Europe”. [9] „examines Russia's entire oil and gas export network and reveals that there is a considerable surplus pipeline capacity, which is likely to endure in the future. It brings to attention surplus capacity as a concept...” [10] point out that „oil pipelines have a strategic importance in the energy supply of the European Union". They then underline that ,the development of oil and storage activities is essential, as well as the establishment of strategic partnerships in oil sector together with the more efficient use of infrastructure and corridors."

As mentioned above, the topic of transportation of crude oil and refined products from the Caspian region to the European Union has received limited attention of researchers. Therefore, it is important to use other sources of information. Among the most interesting and reliable are the publications of international organizations and international financial institutions, data and analytics published by oil companies and specialized journals, oil information agencies and publications of industry consultants and professional associations. Here we can mention the report by [11], which "evaluates the potential demand for oil and oil products transport via the existing rail corridor in the Caucasus, taking into consideration the competition from alternative routes.” And [12], which pointed out that „Particular attention must thus be paid to the question of transportation, and also to the countries of origin, investments in infrastructure, their protection, relations with transit countries, 'competing consumers'-notably China and emerging countries, but also the United 
States-, energy wastefulness in producing countries, and finally, price. Security of supply depends on adequate and reliable infrastructure and must always be thought of in the longterm." A very interesting Study on the Technical Aspects of Variable Use of Oil Pipelines - Coming into the EU from Third Countries was prepared by [13]. The phrase „from Third Countries” in this context means from the former Soviet Union territory. The same report underlines that „Sufficient and reliable availability of crude oil is one of the most important preconditions for economic stability of industrialized economies.” [14] advised that „Historically, Caspian oil and natural gas producers have lacked sufficient export infrastructure. The coastal countries have developed several approaches for international exports. Some countries cooperate and jointly develop oil export capacity, while others focus on attracting enough investment to create their own routes. Kazakhstan and Azerbaijan have had the most success in developing oil export capacity through the construction of the CPC and BTC pipelines, which have become the main transit routes for Caspian oil.” A good projection of the future demand was made by [15]: „Between 2016 and 2040, the transportation sector accounts for two out of every three additional barrels consumed. Nevertheless, demand growth is foreseen to decelerate on the back of efficiency improvements driven by technological developments, a tightening of energy policies and a relatively low (albeit increasing) penetration of transportation fuelled by natural gas and electricity. Oil use for industrial purposes (petrochemicals and other industry) is also expected to increase, though at a slower pace than in the transportation sector. Oil consumed for other uses is forecast to grow marginally, particularly because demand in electricity generation is projected to decline, hence, offsetting some growth in other sectors. Energy poverty alleviation measures, coupled with rising income and urbanization levels, will continue to foster a switch away from traditional fuels to oil-based products." [1] assessed ,the security of demand for the oil and gas of three countries in the Caspian region: Azerbaijan, Kazakhstan, and Turkmenistan, over a 16-year period, capturing the geopolitical situation and contributing to a greater understanding of the impact of energytransporting countries' geopolitical situation on energy transportation to the European Union (EU). The results demonstrate that risk of energy security of demand is greater when political risk in energy-transporting countries is included within a measure of energy security of demand, i.e., risky external energy demand." The issue of the European demand was further developed by [10]: "The greatest oil import in Europe in 2016, which amounted to 500 mil. tons, was realised from Russia, i.e. approx. 35,5\%, then 12,9\% from the West African countries, 12,3\% form the Caspian region”. The traditional point of view that „European Union has always looked to Central Asia as an alternative source to Russia for its energy demand" was expressed by [16]. He then continued that „EU was particularly concerned to find new energy sources. These concerns and needs increased especially after the price 
disputes between Russia and Ukraine in 2006 and 2009 as well as the 2014 Crimean crisis and the consequent sanctions imposition."

\section{Current situation}

\subsection{Demand}

As we can see from Fig. 1 and Fig. 2 below and as already mentioned above, three out of five Caspian countries, namely Azerbaijan, Kazakhstan and Russia, are the largest suppliers of crude oil and refined products to the European Union. Fig. 1 and Fig. 2 can keep us assured that the demand will remain in place in the near future. The author abstains from giving long-term projections because of volatile and unpredictable nature of the oil industry. Please note that terms "refined product" and "petroleum oil" are used interchangeably throughout this document.

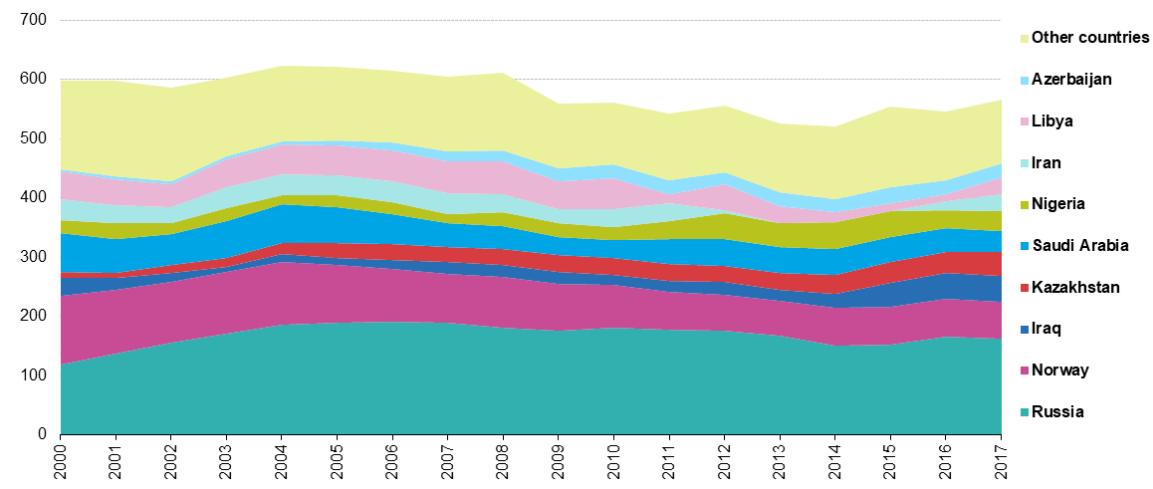

Figure 1. Crude oil imports by country of origin, EU-28, 2000-2017 (million tonnes) [17]

If we wish to consider the percentage growth of the countries under consideration, we receive the results shown in Table 2 below. 
Table 2. Percentage growth of imports from the Caspian Sea region [18]

\begin{tabular}{|c|c|c|c|}
\hline Country & $\begin{array}{c}\text { Crude oil } \\
\text { imports in } \\
\text { 2000, million } \\
\text { tones }\end{array}$ & $\begin{array}{c}\text { Crude oil } \\
\text { imports in } \\
\text { 2017, million } \\
\text { tons }\end{array}$ & $\begin{array}{c}\text { Percentage } \\
\text { growth }\end{array}$ \\
\hline Azerbaijan & 3.7 & 24.1 & $551.35 \%$ \\
\hline Kazakhstan & 9.7 & 39.7 & $309.28 \%$ \\
\hline Russia & 119.5 & 163.1 & $36.49 \%$ \\
\hline
\end{tabular}

2017

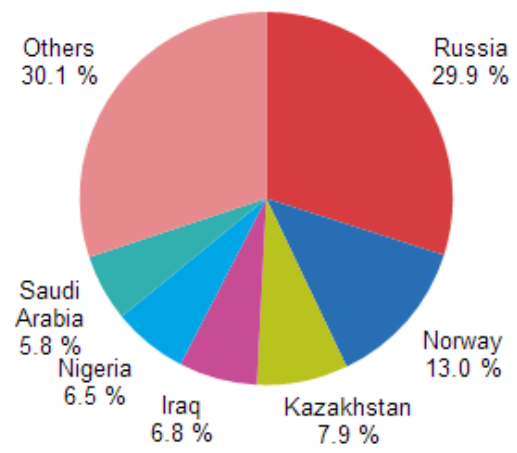

2018

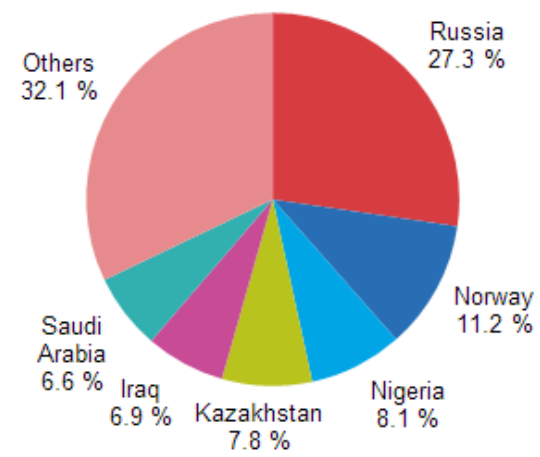

Figure 2. Extra-EU imports of petroleum oil from main trading partners, 2017 and 2018 (share (\%) of trade in value) [19]

Finishing this section, the author would like to refer to [12] who is of the view that "the European Union's hydrocarbon energy supply depends heavily on imports. While the European Commission has recommended diversifying and increasing domestic resources, notably with renewable resources which should grow to $20 \%$ by 2020 , dependence on hydrocarbon imports will remain not only important, but will increase." 


\subsection{Supply and transportation}

The supply and transportation are discussed through the example of each country.

Azerbaijan: Considering this country, we can mention relatively small supplies of crude oil and refined products to the European Union (Fig. 1 and Fig. 2). Main crude export routes go through Georgia and Turkey to the Mediterranean or Black Sea ports and represented by the Baku-Tbilisi-Ceyhan and the Baku-Supsa pipelines. Here and elsewhere please refer to Fig. 3 below for more information about the regional pipeline and port network. Smaller volumes of crude go via the Baku-Novorossiysk pipeline in Russia. Azeri refined products are mainly railed to the Georgian Black sea ports. After reaching sea ports, crude or refined products are transhipped onto tankers and then delivered to the European Union.

Iran: The country has been under Western sanctions for the most of the time since the Iranian revolution of 1979. In the periods when the sanctions were lifted, the country supplied very modest amounts of crude to the European Union, mostly to Italy. Iran never had any substantial oil production in the regions close to the Caspian Sea and can be excluded from consideration in this article.

Kazakhstan: Discussing the supply side, we should note that Kazakhstan is the main producer of crude oil in the Caspian region. "Most of Kazakhstan's crude oil exports travel around or across the Caspian Sea to European markets. A significant portion of Kazakhstan's exports transit Italy and the Netherlands" [20]. The Kazakh crude and petroleum oils go via pipelines or by rail mostly to the Russian Black Sea ports. Substantially smaller amounts transit via the Russian Druzhba pipeline network to Central Europe, Russian Baltic Sea ports, the Baku-Tbilisi-Ceyhan pipeline or Georgian Black Sea ports.

Russia: The country is the main producer of petroleum oils in the Caspian region. The Russian crude oil production in the region is substantially smaller. It is at the same time the biggest transiter. The country possesses the most developed and widereaching transport infrastructure in the region and exercises its geographic advantage extensively. It adopted the policy of reorienting transit freight traffic to the Russian transport infrastructure. In March 2018, the Government Transport Commission of the Russian Federation approved a roadmap for the development of Baltic and Western Arctic seaports and approaches to them until 2020. „Traditionally, Caspian oil and natural gas went directly to Russia through the Soviet pipeline system, where some of it could go to Western markets" [14]. Russia has been trying to keep this advantage.

Turkmenistan: The country holds large reserves of hydrocarbons, but it is distant from key consumer markets. It produces a very high-quality crude, which travels to Europe first across the Caspian Sea, then via the Baku-Tbilisi-Ceyhan or the Baku- 
Novorossiysk pipelines. The refined products mostly shipped by tankers to Russian Black Sea ports via the Volga-Don Ship Canal or to Baku and then to Georgian Black Sea ports.

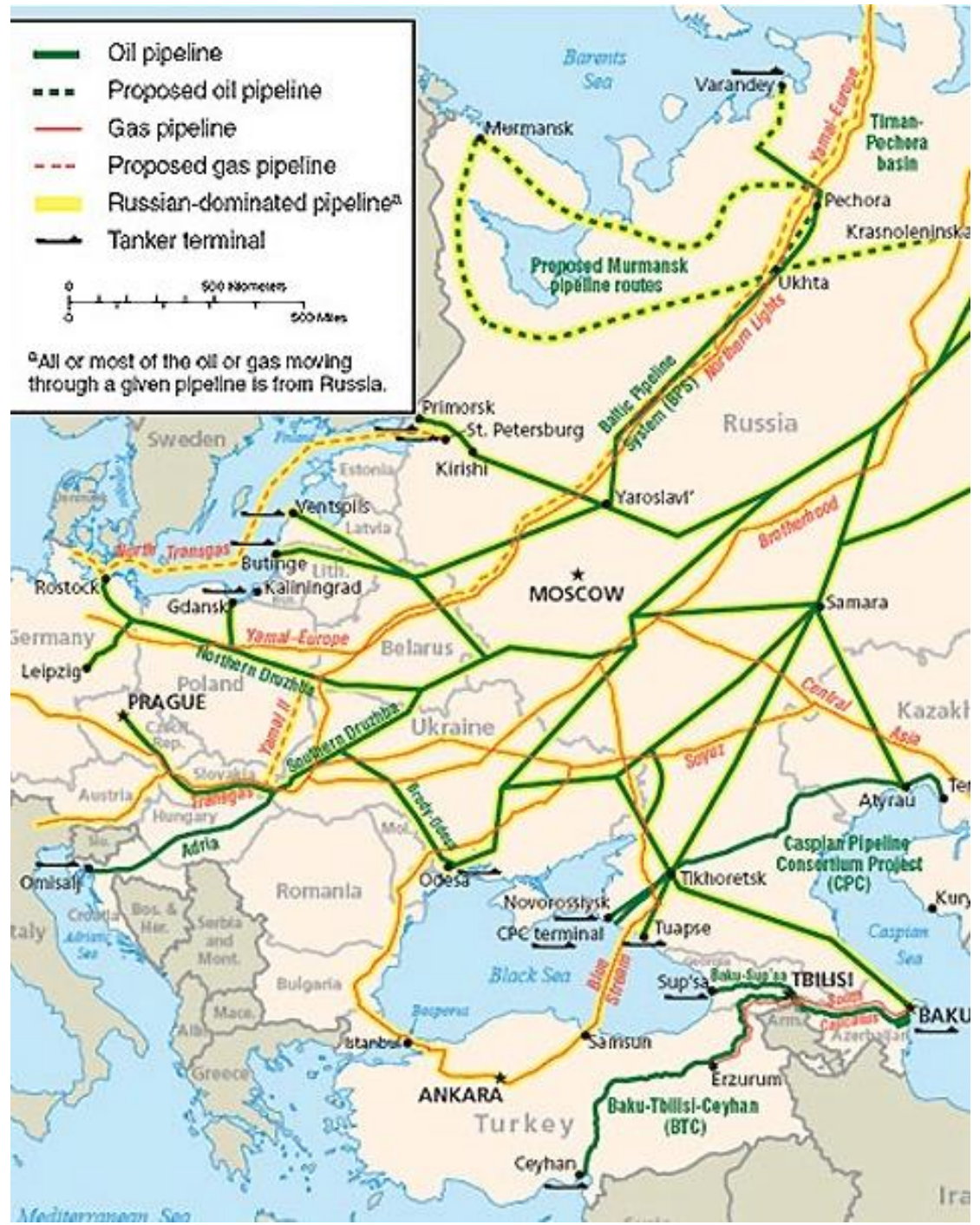

Figure 3. Primary Oil and Gas Pipelines to Europe [25] 
Transportation of crude oil and refined products to the European Union is represented by the following modes:

- Pipeline: mainly used to bring crude oil and certain refined products to sea ports for further transportation. A smaller part of crude is transported to the European Union via pipelines without any trans-shipment;

- Rail: this mode is used in situations when there is no access to crude oil pipelines or the shipper prefers to preserve the quality of its crude (please note the Russian Transneft crude pipeline system does not have a quality bank). Also, it is practically the only mode of transportation able to transport many types of refined products;

- Water (sea and river): the cheapest mode though it has well-known limitations;

- Multimodal: it is represented by different combinations of modes mentioned above and is by far the prevailing mode to transportation.

\section{Existing and potential issues}

In this chapter the author addresses existing and potential issues related to the topic of this article.

\subsection{Demand}

Being by far the most important factor influencing the transportation of crude oil and refined products to Europe and not only from the Caspian region, demand has been and will mainly be influenced by the following:

- Large-scale transfer to renewable sources of energy and introduction of energy efficient technologies. These factors are already well-known to the large audience and are not discussed here for brevity. It should just be mentioned that though substantially limiting the use of hydrocarbons, the renewables will not, in the foreseeble future, replace them completely. So, the demand for hydrocarbons produced in the Caspian region and, hence, their transportation will remain;

- Technological innovations (TIs): For brevity, the author would like to touch upon just two TIs, which already influence the demand side or will do that in the future. The first TI to mention are hybrid and electric vehicles, which have experienced the exponential growth over the last years. As reports [21], the worldwide number of battery electric vehicles in use increased from 112'920 in 2012 to 3'290'800 in 2018. It is evident that this trend will 
continue and the share of conventional vehicles will be decreasing. This is just one, but a very important example of how new technologies affect the market and subsequently form market expectations. Another TI is certainly the introduction of nuclear fusion reactors. Even though lots of engineering issues still remain to be solved, this moment will certainly come and it will decrease the demand for hydrocarbons dramatically;

- Political tensions: this factor has been affecting Russian gas supplies to Europe. There is a probability that it will affect crude and products deliveries as well, but its estimation lies beyond the scope of this article and deserves a separate study.

This section does not consider all the factors, but only those which influence the demand to a significant extent. For example, competition from other suppliers has existed for decades and it is unlikely that it will change the European demand for the Caspian crude and products significantly (please see Figure 1and Figure 2 above).

\subsection{Supply and transportation}

The European Union has been and will remain the main export market for crude oil and petroleum oils produced in the Caspian region. This situation is explained by the following main considerations:

- Primary energy production in the Caspian region is expected to grow within the next two decades. For example, [15] forecast that the crude oil production in Kazakhstan, which is by far the main crude producer in the region grows from 1.6 million barrel a day (mb/d) in 2016 to $2.7 \mathrm{mb} / \mathrm{d}$ in 2040;

- $\quad$ Size of the European market;

- Geographical proximity and well-developed transportation infrastructure;

- The European Union has been the main export market for the Caspian crude and refined products historically.

At the same time, there are different factors and issues that affect or can affect crude oil and refined products deliveries from the Caspian region to the European Union. The main (but not all) ones are:

- Political: interstate conflicts, political sanctions, unequal access to transportation infrastructure, etc.: As mentioned above, this factor has already been affecting Russian gas supplies to Europe. There is no guarantee that the same will not happen with crude oil and petroleum oils. Other political tensions exist as well. For example, the Baku-Supsa pipeline 
„was closed down as a safety measure in August during Georgia's 5-day war with neighbouring Russia." [22];

- Technical: outdated infrastructure, violations of operating procedures, etc.: as reports [23] „Between 19 April and the beginning of June 2019, deliveries of crude oil to refineries in Central and Eastern Europe via the Druzhba pipeline were interrupted due to the contamination of crude oil in the system with organic chlorides.” The same author continued that „The incident highlighted the risk of procedural violations, negligence and direct forgery of documents" even though this was ,the first (incident) on such a scale in the Druzhba pipeline's 50-year history of oil deliveries to Europe". If such incidents continue in the future, there will be a good reason to channel European crude deliveries away from Russian pipeline network;

- Environmental and regulatory: The growing volume of oil traffic through the Turkish Straits is creating significant environmental, public safety and economic risks. In an effort to prevent any possible incident, Turkey introduced new rules for the passage of ships in September 2018 which, „require escorting a tug for more types of vessels than the previous ones”. As a result, ,The waiting time for passage through the straits for tankers leaving the Black Sea is about 16 days (in 2019), which is significantly longer than the usual 5-6 days and is the maximum since 2014." [24]. Another example is the regulations of the International Maritime Organization for ships to cut sulphur oxide emissions commonly called IMO 2020. IMO 2020 bans ships from using fuels with a sulphur content above $0.5 \%$ as of January 2020 as opposed to $3.5 \%$ previously. The new tougher rules are named the biggest shake-up for the oil and shipping industries for decades. The regulations are aimed at improving human health by reducing air pollution.

\section{Conclusions}

Discussing the demand side, we should admit that nothing much can be done about the influence of transfer to renewables and introduction of energy efficient technologies as well as about technological innovations. They are logical historically and environmentally friendly.

On the supply side, there is a real need to improve the governance, risk management and compliance at every stage of crude oil and refined products transportation from the Caspian region to the European Union. This will allow to make the deliveries quicker, safer and cheaper. The improvements will benefit all the stakeholders. 
And, as mentioned above, the estimation of political factors lies beyond the scope of this article, though they affect the situation significantly. More business, less politics could be a good advice, but this is not practical as international politics is always a risk for oil business.

\section{References}

[1] U. Aydin, D. Azhgaliyeva, Assessing energy security in the Caspian region: the geopolitical implications for European energy strategy, Tokyo, 2019.

URL https://www.adb.org/publications/assessing-energysecurity-caspian-region

[2] The World Bank, Country Score Card: Logistics Performance Index, (2020).

URL https://Ipi.worldbank.org/international/scorecard

[3] A.M. Jaffe, Unlocking the assets: energy and the future of Central Asia and the Caucasus main study, Houston, 1998.

URL

https://www.bakerinstitute.org/media/files/Research/98f ba438/unlocking-the-assets-energy-and-the-future-ofcentral-asia-and-the-caucasus-working-papers.pdf

[4] R. Soligo, A.M. Jaffe, The Economics of pipeline routes: the conundrum of oil exports from the Caspian basin, in: Energy in the Caspian Region, Palgrave Macmillan UK, 2002: pp. 109-132. doi: https://doi.org/10.1057/9780230501225_6

[5] G. Bahgat, Pipeline Diplomacy: The geopolitics of the Caspian sea region, International Studies Perspectives. 3 (2002) 310-327. doi: https://doi.org/10.1111/1528-3577.00098

[6] M. Tsereteli, Economic and Energy Security: Connecting Europe and the Black Sea-Caspian region, Central Asia-Caucasus Institute \& Silk Road Studies Program, Washington, D.C., 2008.

URL www.silkroadstudies.org

[7] A. Vatansever, Russia's oil exports economic rationale versus strategic gains energy and climate program, Washington D.C., 2010. URL 
https://carnegieendowment.org/files/russia_oil_exports. $p d f$

[8] J. Marriott, M. Minio-Paluello, The political and material landscape of European energy distribution: tracking the oil road, theory, culture \& society. 31 (2014) 83-101.

doi: https://doi.org/10.1177/0263276414540726

[9] A. Vatansever, Is Russia building too many pipelines? Explaining Russia's oil and gas export strategy, Energy Policy. 108 (2017) 1-11. doi: https://doi.org/10.1016/j.enpol.2017.05.038

[10] D.K. Gordana Sekulić, Dragan Kovačević, Damir Vrbić, Vladislav Veselica, Strategic role of oil pipelines in EU energy supply, Journal of Energy - Energija. 68 (2019).

URL

http://journalofenergy.com/index.php/joe/article/view/6

[11] M. Lawrence, R.B. Sevara Melibaeva, J. Moose, Caucasus transport corridor for oil and oil products, Washington D.C., 2008.

\section{URL}

http://documentsl.worldbank.org/curated/en/628261468017 451524/pdf/686930ESWOP1030ort0CorridorODec008.pdf

[12] S. Nies, Oil and gas delivery to Europe. An overview of existing and planned infrastructures, Paris, 2008.

URL

http: //www. europarl. europa.eu/document/activities/cont/ 200904/20090406ATT53473/20090406ATT53473EN.pdf

[13]F. Kottsieper, Study on the technical aspects of variable use of oil pipelines-coming into the EU from third countries overall report prepared for the directorate-general for energy of the European Commission, Munich, 2010.

URL

https://ec.europa.eu/energy/sites/ener/files/documents/ 2010_reporting_technical_aspects.pdf

[14]EIA, Overview of oil and natural gas in the Caspian Sea region, Washington D.C., 2013.

URL 
https://www.eia.gov/beta/international/analysis_include s/regions_of_interest/Caspian_sea/caspian_sea.p $\bar{d} f$

[15] OPEC, World Oil Outlook 2040, Vienna, 2017.

URL

https://WwW.opec.org/opec_web/flipbook/W002017/W002017/ assets/common/downloads/WOO 2017.pdf

[16]P. Paolo Raimondi, Central Asia oil and gas industry - the external powers' energy interests in Kazakhstan, Turkmenistan and Uzbekistan, Milan, 2019.

URL https://www.feem.it/m/publications_pages/ndl2019$006 \cdot p d f$

[17] Eurostat, Crude oil imports by country of origin, EU-28, 2000-2018 (million tonnes), 2020.

URL https://ec.europa. eu/eurostat/statisticsexplained/index.php?title=File:Crude_oil_imports_by_cou ntry_of_origin,_EU-27,_2000-2018_(mililion_tonnes)_F.png

[18] Eurostat, Crude oil imports by country of origin, EU-28, 2000-2017 (million_tonnes), 2020.

URL https://ec.europa.eu/eurostat/statisticsexplained/images/f/f2/Crude_oil_imports_by_country_of_o rigin:2C_EU-28\%2C_2000-2017_\%28million_tonnes\%29.png

[19] Eurostat, Extra EU imports of petroleum oil from main trading partners, 2018 and 2019, 2020.

URL https://ec. europa. eu/eurostat/statisticsexplained/index.php?title=File:ExtraEU_imports_of_petroleum_oil_from_main_trading_partners, -2018_and_ $201 \overline{9}-$ v2.png

[20]EIA, Background reference: Kazakhstan, Washington D.C., 2019. URL

https://www.eia.gov/beta/international/analysis_include s/countries_long/Kazakhstan/pdf/kazakhstan_bkgd.pdf

[21] IEA, Global EV outlook 2019, Paris, 2019.

\section{URL}

https://nangs.org/analytics/download/4002_6d971ffab5d54 $48 c 049 d 2100 a 16527 c 7$ 
[22] E. Watkins, Baku-Supsa line reopens, BTC ships Kazakh oil, Oil \& Gas Journal. (2008).

URL https://www.ogj.com/pipelinestransportation/article/17268058/bakusupsa-line-reopensbtc-ships-kazakh-oil

[23] V. Yermakov, The Druzhba pipeline crisis: the lessons for Russia and for Europe, Oxford, 2019.

URL https://www.oxfordenergy.org/wpcms/wpcontent/uploads/2019/06/The-Druzhba-Pipeline-CrisisThe-Lessons-for-Russia-and-for-Europe.pdf

[24] M. Herald, More than 50 oil tankers stuck in the queue for passage through the Bosphorus and the Dardanelles, Maritime Herald. (2019). URL https://www. maritimeherald.com/2019/more-than-50oil-tankers-stuck-in-the-queue-for-passage-through-thebosphorus-and-the-dardanelles/

[25] K. Borisocheva, Analysis of the Oil-and Gas-Pipeline-Links between EU and Russia. An account of intrinsic interests, Athens, 2007.

URL https://www.files.ethz.ch/isn/47031/Analysis Oil and Gas.pdf 